\title{
The holdings markup behavior of mutual funds: evidence from an emerging market.
}

Authors: $\quad$ Wang, Ching-Chang ${ }^{1}$ johnsig@stust.edu.tw

Yu, Jerry²cyu@ubalt.edu

Source: $\quad$ Review of Quantitative Finance \& Accounting. Feb2018, Vol. 50 Issue 2, p393-414. 22p.

Document Type: $\quad$ Article

Subject Terms: $\quad{ }^{*}$ Mutual funds

*Emerging markets

*Markup

*Market capitalization

Geographic Terms: Taiwan

Author-Supplied G20

Keywords: $\quad$ G23

Holdings markup

Price markup

Return seasonality

NAICS/Industry 525910 Open-End Investment Funds

Codes: $\quad 525990$ Other Financial Vehicles

523990 All other financial investment activities

522299 All other non-depository credit intermediation

523920 Portfolio Management

Abstract: $\quad$ This paper uncovers a seasonal mutual fund holdings markup pattern in Taiwan's market. Specifically, we find that fund's equity holdings jump up significantly at the quarter-ends and year-end while drop back immediately to the previous level in the following month. While the holdings markup pattern found in this paper 
may look similar to the price markup phenomenon found by Carhart et al. (J Finance 57:661-693, 2002), the mechanism used by fund managers in the performance inflation may be quite different. In specific, while Carhart et al. (J Finance 57:661$693,2002)$ document that fund managers use the stocks currently held in their portfolio to mark up the fund performance, we find that fund managers in fact use both the stocks already held in their portfolio and the new stocks to mark up their holdings. Furthermore, Carhart et al. (J Finance 57:661-693, 2002) do not explicitly examine if there exists a holdings markup in addition to the price markup. In this study, we fill this gap by directly exploring the holdings markup behavior by the fund managers. We also identify the specific stock characteristics that fund managers prefer in their holdings markup. In specific, fund managers prefer to trade growth stocks, stocks with larger market capitalization, higher institutional ownership, higher quality of earnings, and stocks in the high-tech industry, to inflate the fund performance. We also find that fund managers tend to avoid stocks that are herded by other funds. [ABSTRACT FROM AUTHOR]

Copyright of Review of Quantitative Finance \& Accounting is the property of Springer Nature and its content may not be copied or emailed to multiple sites or posted to a listserv without the copyright holder's express written permission. However, users may print, download, or email articles for individual use. This abstract may be abridged. No warranty is given about the accuracy of the copy. Users should refer to the original published version of the material for the full abstract. (Copyright applies to all Abstracts.)

Author Affiliations: $\quad{ }^{1}$ Southern Taiwan University of Science and Technology, Tainan City, Taiwan ${ }^{2}$ Merrick School of Business, University of Baltimore, $1420 \mathrm{~N}$. Charles Street, 21201, Baltimore, MD, USA

ISSN:

0924-865X

DOI:

$10.1007 / \mathrm{s} 11156-017-0633-1$

Accession Number: 127379918 


\section{Database: $\quad$ Business Source Complete}

\section{$\Theta$ Adjusting Location Display...}

\section{The holdings markup behavior of mutual funds: evidence from an emerging market.}

\section{American Accent v (1) 券}

This paper uncovers a seasonal mutual fund holdings markup pattern in Taiwan's market. Specifically, we find that fund's equity holdings jump up significantly at the quarter-ends and year-end while drop back immediately to the previous level in the following month. While the holdings markup pattern found in this paper may look similar to the price markup phenomenon found by Carhart et al. ( $\mathrm{J}$ Finance 57:661-693, <xref $>2002</ x r e f>$ ), the mechanism used by fund managers in the performance inflation may be quite different. In specific, while Carhart et al. (J Finance 57:661-693, <xref $>2002</ x$ ref $>$ ) document that fund managers use the stocks currently held in their portfolio to mark up the fund performance, we find that fund managers in fact use both the stocks already held in their portfolio and the new stocks to mark up their holdings. Furthermore, Carhart et al. (J Finance 57:661-693, <xref $>2002</ x r e f>$ ) do not explicitly examine if there exists a holdings markup in addition to the price markup. In this study, we fill this gap by directly exploring the holdings markup behavior by the fund managers. We also identify the specific stock characteristics that fund managers prefer in their holdings markup. In specific, fund managers prefer to trade growth stocks, stocks with larger market capitalization, higher institutional ownership, higher quality of earnings, and stocks in the high-tech industry, to 
inflate the fund performance. We also find that fund managers tend to avoid stocks that are herded by other funds.

Mutual funds; Holdings markup; Price markup; Return seasonality; G20; G23

\section{Introduction}

Carhart et al. ([ 4] ) find a striking result regarding mutual fund managers' price markup behavior at the quarter-ends and year-ends, at the time when funds' performances are usually to be evaluated. They call this phenomenon "leaning for the tape", indicating that mutual fund managers intend to enhance the performance ranking of their funds right before the time when the funds are evaluated. Thus, it is in some way analogous to the situation where the runners, especially the leading ones, are competing to each other for leaning for the tape in the last few seconds in a track tournament.

The findings by Carhart et al. ([ 4] ) suggest that fund managers tend to inflate quarter-end portfolio prices with last-minute purchases of stocks already held. This evidence suggests that the positive correlation between fund flows and investment performance might be the major motivation inspiring managers to inflate prices of the stocks that are already in their portfolios. Instead of a mutual fund price markup at quarter-ends found by Carhart et al. ([ 4] ), we find a mutual fund stockholdings markup at the quarter-ends in Taiwan's market. Specifically, we find that fund managers tend to increase their equity holdings at both the quarter-ends and year-end followed by immediate cut-back on the holdings in the following month. This holdings markup behavior is as striking as the price markup found by Carhart et al. ([4] ). Although the motivation may be the same for fund managers to engage in both of the markup behaviors, it is essentially quite different in terms of the implication and the mechanism used in reaching the goal of enhancing the portfolio performance.

First of all, the price markup does not necessarily imply there will be a holdings markup. For example, fund managers may buy and sell different shares in the same time for the purpose of price markup, which may not lead to a significant 
change in their portfolio holdings. Since Carhart et al. ([ 4] ) do not explicitly examine whether there exist significant changes in holdings at the quarter-ends and year-end, this study tries to fill this gap by showing the existence of the holdings markup.

Secondly, the price markup documented by Carhart et al. ([ 4] ) implies that fund managers engage in pushing up the share prices of the stocks that they have held in their portfolios. However, the holdings markup evidenced in this paper suggests that fund managers may also try to use new stocks in addition to the stocks already held in the fund portfolio, to temporarily enhance their portfolio performances.1 [ 1]

By further investigating the funds holdings pattern after controlling for the market return, we find that the increasing pattern of the funds holdings at the quarterends and year-end is unlikely to be induced by fund managers' passive trendchasing behavior. This asserts that mutual funds' holdings markup is not caused by the market movement but, instead, a result of the fund managers' active trading decision.2 [ 2]

In addition to the findings of the holdings markup by fund managers, we also further examine whether fund managers have preferences on stocks with certain styles or characteristics as their potential markup targets. It has been documented in finance literature that fund's performance is related to the stock styles or characteristics. For example, Bhargava et al. ([1] ) find that mutual fund's performance is related to its asset allocation and investment style, as its holding targets are primarily subjected to fund's type.

In order to address this issue, we categorize stocks into different groups according to the following commonly used stock characteristics: cash flow per share, price-earnings ratio, book-to-market ratio, market capitalization, previous month's return and the institutional ownership level. And since stocks in the hightech industry have played a dominant role for decades in Taiwan's market, we also use a high-tech stock indicator to specify those stocks in the high-tech 
industry. Furthermore, we add a variable regarding herding in order to see if fund managers herd in their holdings markup.

The empirical results show that fund managers indeed have specific preferences on the types of stocks that they target on for the holdings markup. Specifically, the potential markup target stocks tend to be those with larger market capitalization, higher institutional ownership, higher earnings quality, and in the high-tech industry. Those stocks tend to be traded more frequently and thus more liquid. Therefore, the above findings imply that fund managers attempt to minimize the liquidity risk involved in the holdings. Furthermore, we also find that fund managers prefer stocks that are not herded by other funds. This result implies that fund managers try to be more effective when marking up holdings to enhance their funds' rankings among all of the funds by avoiding stocks with high degree of herding.

The motivation for fund managers to engage in such a holdings markup strategy at the quarter-ends and year-ends may be because that they attempt to enhance their portfolios performance at the quarter-ends since mutual funds are usually evaluated at the end of each quarter. If this is the case, then we should observe a jump in funds' performance at the end of each quarter followed by a decrease in performance in the following month.

In order to examine whether fund managers are motivated by the temporary performance-enhancing attempt in the holdings markup phenomenon, we compare the excess returns of the fund portfolios at the quarter-ends with those in the following month (quarter-begins). The result shows that there indeed exists a significant pattern where fund performance jumps significantly at the end of each quarter followed by a significant decrease in performance in the following month. This evidence supports the suggestion that fund managers are motivated by temporarily enhancing their portfolio performance at the quarter-ends for the periodical evaluation purpose. 
The remainder of this paper is organized as follows. The next section provides some existing findings in current literature regarding return seasonality for both stocks and mutual funds. Section 3 describes the data and the source of data. Section 4 outlines the research design and provides the analysis of our empirical results. And finally, Section 5 concludes the paper.

\section{Return seasonality of stocks and mutual funds}

Numerous studies have evidenced stock return seasonality in the recent three decades. For example, Keim ([19] ) documents that stock prices of small-cap firms go up in the first 5 days after year-end and this upward trend cannot be fully explained by risk factors. Based on Keim's paper, subsequent studies offer different explanations for the observed seasonality of stock returns. Roll ([22] ), for example, argues that investors would sell shares with poor performance to realize losses for reducing tax expenses. After realizing the tax-loss selling, those investors would promptly buy back shares, which results in share price increase around the year-begin. Another explanation for such a stock return seasonality is window dressing. Studies by Haugen and Lakonishok ([15] ) and Musto ([20] ) both focus on the rising of the stock prices around the beginning of the year. Their results indicate that the phenomenon of the increase in share price at the beginning of the year is primarily originated by institutional investors who buy back shares with poor performance at the beginning of the year. Thus, their findings imply that institutional investors may play an important role in the stock return seasonality.

Among the return seasonality of institutional players in the market, mutual funds have drawn most of the attention in finance literature. There are some evidences in the current literature regarding mutual fund's return seasonal patterns. For example, Zweig ([26] ) finds that US equity mutual funds exhibit stronger positive returns around year-ends. In particular, on the last trading day of a year, mutual funds' returns are higher than the S\&P 500 index return by about $0.53 \%$. Zweig also finds that those higher fund returns will usually be reversed on the next year's first trading day, having returns lower than S\&P 500 by about $0.37 \%$. 
Zweig suspects that some mutual fund managers may have raised their portfolio performance at the end of the year by means of strategic additional trading.

Zweig ([26] ) does not provide the reason why mutual fund managers attempt to enhance portfolio performance at the year-ends. Later on the empirical results documented by Ippolito ([17] ) and Sirri and Tufano ([23] ) at least partly provide the incentive for mutual fund managers to engage in the above-mentioned yearend fund return increase pattern observed by Zweig. In examining the sensitivity of fund flows to fund's performance, Ippolito ([17] ) and Sirri and Tufano ([23] ) both find that net fund flows are much sensitive to fund's return for the top winning funds and the bottom losing funds. This finding implies that funds with the best past performance may profit more from the increase in fund flows, while funds with the worst performance may suffer the most from the decrease in fund flows.

The increase (decrease) in fund flows may, in turn, imply an increase (a decrease) in fund manager's compensation. It has been well documented that there exists a positive relationship between the degree of competition and the economic incentives related to management fee revenues (e.g., Starks [24] ; Grinold and Rudd [14] ; Cohen and Starks [8] ; Grinblatt and Titman [11] , [12] ; Golec [10] ). Thus, in order to gain higher management compensation, fund managers may strive to achieve higher performance at the end of the year when their funds are evaluated. Orphanides ([21] ) and Brown et al. ([3] ) both find a completely different attitude toward risk from managers of the top winning funds versus those of the bottom losing funds. They find that in the middle of the year, managers of losing funds tend to take more risk toward year-end than those of winning funds.

The recent findings by Carhart et al. ([ 4] ) regarding fund managers' performance chasing behavior at the year-end and quarter-ends carry somewhat different features from what have been documented before. Basically, they find that fund managers tend to mark up fund returns at the quarter or year-ends in order to temporarily enhance their portfolio performances by intentionally 
affecting the market prices of the shares in their portfolios. In our paper, we find a different mutual fund's seasonal pattern than what Carhart et al. ([ 4] ) have documented. Instead of mutual funds' price markup, we find a portfolio holdings markup both at the end of the quarters and at the end of the year. While fund manager's motivation of both price markup and holdings markup may be the same, the mechanism used in achieving the goal of attempting short-term portfolio performance in those two markup behaviors can be quite different. The price markup does not necessarily lead to holdings markup. And, the finding of price markup by Carhart et al. ([4] ) suggests that fund managers are able to affect the market price of the shares already held in their portfolios, while our finding of the holdings markup shows that fund managers tend to use both new stocks and the stocks already held in their portfolio for temporarily enhancing their fund performance.

\section{Data}

The data used in this paper consists of all of the stocks held by the equity mutual funds from two databases, CMoney and Taiwan Economic Journal (TEJ). The monthly shareholdings of all of the sample funds are collected from CMoney database because it provides more complete data of fund's holdings. All of other data, such as fund's NAV, firm's financial statement data and securities market returns data, are collected from TEJ database. The sample period used in this study is from January 1993 through December 2013 when monthly shareholdings and net asset values of the equity funds are available.

Furthermore, we partition all sample funds into the following four specific categories that are commonly used by the funds and the investors in Taiwan: equity-in-general funds, small-cap funds, high-tech funds, and balanced funds.3 [ 3] When closed-end funds are switched into open-end funds, they are incorporated into one of the corresponding fund types from the following month of the effective date of the switching.

In order to identify the firm characteristics of mutual funds' holdings markup targets, we also collect the following firm specific characteristics data: price- 
earnings ratio, cash flows per share, book-to-market ratio, firm capitalizations. The data of monthly institutional holdings for all listing firms, as well as the monthly individual stock returns data over the sample period are also obtained from TEJ database. Furthermore, since the high-tech industry has been the dominant sector in Taiwan's market for decades, we also use the four-digit industrial code from Taiwan Security Exchange (TSE) to identify the stocks that are in the high-tech industry.

\section{Research design and empirical results}

\section{Seasonality of the funds' shareholdings}

We start by examining mutual funds' monthly shareholdings to investigate whether funds' shareholdings exhibit any seasonality pattern. We calculate the average monthly shareholdings and the changes in holdings around each turn-ofthe-month. The results are reported in Table 1, with Panel A showing the results for the full fund sample, while Panels $B, C, D$ and $E$ showing those for the equityin-general, small-cap, hi-tech, and balanced funds, respectively.

It is clear from Table 1 that the monthly holdings of mutual funds exhibit significantly quarterly-cycle pattern. That is, for every quarter-end the funds' shareholdings jump up and then slide down in the following month. For example, the result from Panel A for the full fund sample shows that funds' shareholdings increase sharply by $9.94 \%$ in the month of March and then cut down by $7.30 \%$ in the next month. In the month of June, i.e., the end of second quarter, funds' holdings jump by $6.64 \%$ but then slide down by $6.56 \%$ in the following month. The exactly same pattern happens in both September and December as well. Thus, for the full sample of funds, the pattern is quite clear that funds' holdings exhibit a consistent jump at quarter-end and immediately followed by a decrease in the following month. Since mutual funds are usually evaluated at the end of each quarter, the consistent quarter-end jump in funds' holdings implies that fund managers may have used a holdings markup strategy trying to inflate their quarter-end performance in order to shoot for a better evaluation ranking. 
For the specific fund categories shown in Panels B, C, D and E, the results are the same as those found in Panel A in terms of the funds' holdings and holdings changes. That is, the funds' holdings tend to increase at the end of quarters but diminish to a normal level at the following month. This result suggests that no matter which types of funds we are looking at, funds' holdings always exhibit a seasonal pattern where funds' holdings jump up at the quarter-ends, followed by a sudden cutback in the following month.

Since mutual fund performances are typically evaluated at the end of the quarters, one might suspect whether this seasonality of the funds' shareholding cycle is related to fund managers' intention to enhance or "window-dress" their portfolio performance in order to gain higher performance ranking at the time of the fund evaluation. Since the fund rankings will directly affect fund manager's compensation, especially around the quarter-ends and year-end, it is reasonable to suspect that fund managers will have the intention to markup their holdings in order to improve their portfolios' rankings.

In order to present the seasonality pattern of the funds holdings more clearly, we also show it in Fig. 1. It is obvious from Fig. 1 that the funds' shareholdings increase sharply at the quarter-ends and then decrease almost at the same percentage in the following month. And, except for the small-cap funds, the change in holdings at the year-end exhibits the most pronounced pattern. This also coincides with the fact that typically the year-end has been the most important timing in terms of mutual funds performance evaluation. And, therefore, fund managers have more incentive to inflate their fund performance and rankings at the year-end.Average percentage changes in fund's holdings across the months. This figure shows the average percentage changes in fund's holdings across the months for the "all funds" sample and for each of the specific fund categories: equity-in-general, small-cap, hi-tech, and balanced funds, respectively. The horizontal axis represents the months of the year. The vertical axis denotes the average percentage changes in holdings 
To provide further evidence on the seasonal pattern of funds' holdings, we also conduct the following indicator-variable regression for both the full funds sample and for each of the specific fund categories.SH $=\gamma 0+\gamma 1 \mathrm{QEND}+\gamma 2 \mathrm{QBEG}+\gamma 3 \mathrm{YEND}+\gamma 4 \mathrm{YBEG}+\varepsilon$, where $\mathrm{SH}$, the dependent variable, denotes the funds' monthly shareholding; $\varepsilon$ is the regression error; and QEND, QBEG, YEND and YBEG are all dummy variables whose values are set as follows:QEND=1,for the months of each quarter-endMarch, June, September=0,for other months; $Q B E G=1$, for the first month in each quarter $=0$, for other months; YEND $=1$, for the month of December $=0$,for other months $Y B E G=1$, for the month of January $=0$, for other months

The results of the above regression are summarized in Panel A of Table 2. First of all, it is clear from Panel A that all of the coefficients of both QEND and YEND are significantly positive. That means the fund's holdings increase significantly at both quarter-ends and year-end. Secondly, none of the coefficients of the quarter-begins (QBEG) and year-begin (YBEG) is significant, which means that the fund's holdings at the both the quarter-begins and the year-begin are not significantly different from other in-between-quarter months. In other words, the above results indicate that fund managers mark up the shareholdings at both the quarter-ends and year-end and then cut back the holdings to the normal level in the following month.

Several articles evidence that fund managers tend to hold stocks with upward trend and result in a significant holding pattern caused by trend-chasing or momentum behavior (e.g., Jegadeesh and Titman [18] ; Grinblatt et al [13] ; Chan et al. [5] ). And, the trend-chasing behavior of institutional investors exists not only in the developed markets, but can be found in the emerging markets as well (e.g., Chen et al. [6] ). Note that if fund managers were trend chasers, abnormally high shareholdings should be easily found in a good market state. Thus, if the pattern of the stock market returns coincides with the seasonal pattern of funds' shareholdings around quarter-ends and year-end, as found in the above empirical results, the seasonality of the fund holdings may not be the result of fund managers' intention to temporarily enhance their portfolio 
performance. But, instead, it could be simply the artifact of fund managers' return-chasing behavior.

To exclude the possibility of the fund's above-mentioned market-trend chasing behavior, we take into account the market return in the following regression. Specifically, we use the same regression specification as in Eq. (1) with a slight modification. In Eq. ( 2) below, the model adds contemporaneous market return as a control variable to drive out the possible trend-chasing component.

\section{$\mathrm{SH}=\gamma 0+\gamma 1 \mathrm{QEND}+\gamma 2 \mathrm{QBEG}+\gamma 3 \mathrm{YEND}+\gamma 4 \mathrm{YBEG}+\gamma 5 \mathrm{MRTN}+\varepsilon$, where MRTN} represents contemporaneous market return. The other variables bear the same definitions as those in Eq. (1). By adding market return variable, the estimates of this regression are given in Panel $B$ of Table 2. As we can see from Panel $B$, the results with the market return variable included basically are the same as those in Panel A, with almost the same magnitudes of the coefficients. Thus, this result suggests that the market state is not a factor causing the seasonal pattern of fund's holdings.

Next, in order to find out how much proportion of the funds exhibiting the quarterend holdings markup pattern, we report in the first row of each of the fund categories in Table 3 the percentage of the funds that act this way in each of the fund categories. And, the second row shows the difference in that percentage between the fourth quarter and each of the first three quarters, respectively. And, the last row reports the t-statistics of that difference.

First of all, the fund percentage numbers from Table 3 show that although each quarter varies in terms of the percentage of funds showing holdings markup, for all of the funds as a whole there are $59 \%$ of funds on average acting that way, with the hi-tech funds showing the highest average percentage of $66 \%$. Secondly, the percentage at the fourth quarter, i.e., year-end, is the highest among all of the quarters, and for all of the fund types. This indicates that there are more funds engaging in the holdings markup at the year-end. This is consistent with the fact that year-end performance evaluation is much more important than the quarter- 
end ones, thus promoting more funds to engage in such a holdings markup at the year-end than at the quarter-ends.

\section{Fund managers' motivation for the holdings markup}

In order to explore fund managers' motivation for the fund holdings markup activities, we further examine the performance of funds at the quarter-ends versus that in other months. If fund managers' purpose of raising holdings at the end of quarters is to enhance their portfolio performance to gain preferable fund rankings, we should observe an increase in fund performance at the quarterends and a decrease in fund performance in the following month.

To investigate the above phenomenon, we use the following regression to gauge funds' excess returns over different months:ER $=\gamma 0+\gamma 1 Q E N D+\gamma 2 Q B E G+\gamma 3 Y E N D+\gamma 4 Y B E G+\varepsilon w h e r e$ ER denotes the excess return on a fund's NAV, which is measured by the difference between percentage change of $\mathrm{NAV},\left(\mathrm{NAV}_{\mathrm{i}, \mathrm{T}}-\mathrm{NAV}_{\mathrm{i}, \mathrm{T}-1}\right) / \mathrm{NAV}_{\mathrm{i}, \mathrm{T}-1}$, and the market return in the same month. The rest of the notations in Eq. (3) bear the same definitions as those in Eqs. ( 1) and ( 2) above.

Table 4 reports the estimated results of the above regression. In Table 4, the coefficients of QEND, which represents the first three quarters, are all significantly positive for all of the funds, including each of the specific fund categories. In addition, in all of the funds except the balanced fund, the coefficients of YEND are significantly positive. This indicates that mutual funds' holdings markup does result in the enhancement of the fund performance at both quarter-ends and year-end.

Next, the coefficients of both the quarter-begins and the year-begin are in general negative, with some significant in the categories of all funds, equity-in-general, hitech and balanced funds. That means, in general, fund's performances decrease at both the beginning of the quarter and the beginning of the year, following the above-mentioned performance increase at the quarter-ends and year-end. 
The above results indicate that fund manager's holdings markup does bring higher performance to the fund. Thus, it evidences that the motivation of fund manger's holdings markup is to boost fund's performance at the time when fund's performances are evaluated.4 [4] As to why fund managers mark up the holdings only at the quarter-ends instead of other months or anytime other than the quarter-ends, there are two plausible explanations. Firstly, because a fund manager's performance is usually evaluated at the quarter-ends and year-end, naturally the fund manager will have the incentive to enhance her performance by marking up her portfolio holdings at that time. Marking up holdings during months other than the quarter-ends and year-end would be a riskier move because the longer time she waits from the time she purchases the shares to the end of the quarter or the year, the more uncertainty she would have to face in terms of the possible falling of the share prices, thus hurting her performance.

Secondly, marking up holdings at the quarter-end and year-end months can be more efficient and can also help reduce the risk being followed or imitated by other funds. If a fund manager increases a particular shareholding earlier than the quarter-ends or year-end, other funds may act the same way around the same time, and as a result it could be detrimental to her effort to enhance her fund ranking.

\section{Holdings markup targets}

Basically, fund managers can have two choices to inflate funds performance by increasing (buying) more equity holdings. One way is to buy stocks that are already held in the fund's portfolio, i.e., existing stocks. Another way is to buy stocks that are not yet in the fund's portfolio, i.e., new stocks. Which way fund managers will go for essentially depends on what fund managers believe will be more effective in boosting up fund's performance in a short time period. Since trading more securities will incur higher trading costs and those adds-on trading costs will eventually erode fund's net performance, fund managers will strive to trade stocks that will most likely enhance fund's performance as fast and as effective as possible. 
First of all, by using the strategy of buying stocks that a fund has already had, fund managers need to push the demand for those stocks to a level that will effectively boost up the prices of those stocks and thus gear up the fund's performance. This strategy may not be that easy since there is no guarantee that one fund manager is able to push up the market price of the shares by her own buying effort. In order to use this strategy more effectively, fund manager may need to induce other fund managers' demand on the same group of stocks, which may be even more uncertain.

Secondly, as found in the extant literature that fund managers tend to herd in their trading,5 [ 5] many stocks may be held in the portfolios of different mutual funds. Thus, marking up prices of those stocks may also mark up the performance of other funds, which, in turn, will not be able to boost up the relative performance of a particular fund manager's performance.

Alternatively, a fund manager may also buy stocks that are not in the fund's current portfolio but their prices have a good potential to be higher. Thus, fund manager's buying more of these stocks may also effectively enhance a fund's performance, as long as other fund managers have not herded on those stocks in the same time.

In order to identify the new versus the existing stock targets for the holdings markup, we divide the sample stocks into three groups: "new target stocks", "existing target stocks" and "non-markup stocks". This procedure is conducted by searching every stock that is held by each fund in the following way.

First of all, the "non-markup stocks" contain those stocks whose holdings have been increased in a fund at the quarter-end but they stay in that fund's portfolio in the following month. That is, although a fund manager increases those stockholdings at the quarter-end, she does not drop them after the quarter-end. That means the fund manager has no intention to use those stocks as the markup target. 
On the other hand, if a fund increases holding on a stock at the quarter-end and then immediately drop that stock in the following month, then that stock is identified as a target for the markup. This makes sense because fund manager would not tend to hold a markup target for a long time if her purpose is simply to temporarily enhance her portfolio's performance. However, whether that stock belongs to the new target stock or the existing target stock will depend on if that particular fund has already held that stock in its portfolio or not. If that stock has (not) been in the fund portfolio, then it will be identified as the existing (new) markup target.

In order to test whether there is any difference in terms of the performance result of the holdings markup by using the existing versus the new stocks, we use the following two indicator-variable regressions. $E R=\gamma 0+\gamma 1 M K U P+\varepsilon, E R=\gamma 0+\gamma 1 N e w+\gamma 2 E x i s t i n g+\varepsilon$, where $E R$ is the excess return of the individual stock; MKUP is a dummy variable whose value equals to one for the holdings markup targets (either new or existing) and zero for others; New is a dummy variable whose value is one for the new target stocks and zero for others; Existing is also a dummy variable whose value is one for the existing target stocks and zero for others.

The results of the above regressions are presented in Table 5. Panels A and B report the results for the new target stocks and the existing target stocks, respectively, which are the results of Eq. (4), while panel $C$ reports the result of Eq. (5), which combines the new and existing target stocks in one regression.

First of all, there exists a quite clear pattern from all of the three panels. That is, all of the regressor's coefficients in all of the three panels are significantly positive, including Panel $\mathrm{C}$ where both of the new and existing target stocks are included in the same regression. Secondly, the comparison between the coefficients of the regressor and those of the constant term suggests that both the existing and the new markup targets earn significantly higher returns than the non-markup stocks. For example, in Panel C, all of the coefficients of the regressors, either new or existing target stocks, are significantly positive, while 
those of the constant term are significantly negative. Since the coefficient of the constant term here represents the return result of the non-markup stocks, the contrast results between the coefficients of the regressors and that of the constant term indicate that the markup stocks, either new or existing, earn higher returns than the non-markup stocks.

Basically, the results shown in Panel B are quite similar to those in Panel C, except that the constant term in Panel B now also includes the new target stocks. That is probably why the coefficients of the constant term in Panel B are not as significant as those in Panel $\mathrm{C}$, and some of them even turn into positive. And, for the same reason, most of the coefficients of the constant term in Panel A turn positive because the constant term here also includes the existing target stocks, which consist of the majority of the markup targets, as shown in Table 6 below.

Panels A, B and C in Table 6 report the percentages of the holdings in a fund on average at each of the quarter-ends for the new, existing and the non-markup stocks, respectively. Since the result for each of the specific fund categories is the same as that for the "All Funds" sample, we only show in Table 6 the result for the "All Funds" sample. The second row in each of the panels reports the difference in holdings percentage between each of the first three quarters and the fourth quarter, i.e., year-end, with the third row showing the Z-statistics for the results.

First of all, it is quite clear from Table 6 that the percentage of the new target stocks is far less than those of the existing or non-markup stocks. The average percentage for the new target stocks is only roughly $6 \%$, compared to the averages of about $22 \%$ and $69 \%$ of the existing and non-markup stocks, respectively.6 [6] That means fund managers prefer to mark up the holdings of the stocks that are already held in the fund. This is consistent with the portfolio pumping documented in the literature.7 [ 7]

Secondly, the difference in holdings between the year-end and each of the three other quarter-ends are all significant except the one in the third quarter-end for 
the new markup stocks. This result means that fund managers tend to be more active on holdings markup at the year-end compared to those activities at other quarter-ends. This is consistent with the fact that year-end is the most important fund evaluation timing among all of the quarters, and thus, fund managers would have more incentive to engage in holdings markup to boost their funds' performances at the year-end.

\section{Fund managers' preferences on characteristics of the markup targets} In addition to the above findings regarding the effectiveness of the potential target stocks, it is also interesting to examine whether fund managers exhibit any particular preferences on the types or characteristics of the stocks that they use for the holdings markup. To address this issue, we use the following regression model with several important and most commonly used stock characteristic variables to identify if fund managers have particular preferences on any particular types of stocks, for all funds sample and for each of the fund categories, respectively: $\triangle \mathrm{MH}=\gamma 0+\gamma 1 \mathrm{CF}+\gamma 2 \mathrm{PE}+\gamma 3 \mathrm{BME}+\gamma 4 \operatorname{InMV}+\gamma 5 \mathrm{IHI}+\gamma 6 \mathrm{MQRTN}+\gamma 7 \mathrm{INDTY}-$ $\mathrm{Y} 8 \mathrm{HERD}+\varepsilon$, where $\Delta \mathrm{MH}$ is the monthly percentage change of fund's holding; the stock characteristic variables include: $C F$, cash flow per share; $\mathrm{PE}$, price-earnings ratio, BME, book-to-market ratio; In(MV), natural log of the market value of the firm; IHI, institutional ownership; MQRTN, previous month's return, and INDTY, a dummy variable whose value equals to one if the stock is in the high-tech industry and zero if other than high-tech industry; and HERD is a variable capturing the degree of herding among the funds.

The reason why we segregate out the high-tech industry is because the hightech industry has been playing a dominant role in Taiwan's stock market. And, the HERD measure is adopted from Christie and Huang (1995), where HERD represents the cross-sectional standard deviation of returns, CSSDt $=\sum i=1 \mathrm{NRi}, \mathrm{t}-$ $R m, t 2 N-1$, where, $R_{i, t}$ is the return of stock $i$ at time $t$ and $R_{m, t}$ is the market return at time t. According to Christie and Huang (1995), investors will tend to give up their own beliefs to follow the market, thus, individual stock return will be closer to the market return, i.e., CSSD will decrease, if there exists higher degree of 
herding. In other words, the higher herding activity there is, the lower CSSD would be. And, since we use HERD in Eq. (6) to represent CSSD measure, a lower HERD figure means higher degree of herding. Therefore, in order to have the sign of the HERD coefficient to be consistent with the degree of herding, we add a negative sign in front of the HERD variable in Eq. (6) above, so that a higher value of the HERD coefficient would suggest a stronger herding activity.

Equation ( 6) above is used for the existing, new and non-markup stocks, and the results of each of them are reported in Tables 7, 8 and 9, respectively. In the following we compare the coefficient of each of the stock characteristic variables among those three tables in order to present fund's preferences on the stock characteristics in a holistic manner.

First of all, the coefficients of CF show quite different patterns among the three tables, where no significance is found for the new target stocks, some positive significance for the existing target stocks and all negative significance for the non-markup stocks. Because CF signifies the quality of earnings, the above result implies that fund managers try to avoid stocks with low earnings quality, and prefer those with higher earnings quality, when they choose the stocks for the holdings markup. The insignificance of the CF coefficient for the new target stocks can be due to the low percentage of them used in the markup activity, which is reported in Table 6 above.

Secondly, by comparing the coefficients of PE and BME among those three tables, we find that fund managers prefer to use growth stocks as the holdings markup target. This is implied from the result that shows positive (negative) sign on the PE (BME) coefficient for the existing target stocks and the opposite result on BME coefficient for the non-markup stocks. The result for the new stocks on BME is similar to that for the existing stocks, while no significance shown on the $\mathrm{PE}$, which again may be due to the low proportion of new stocks being used for markup. 
Thirdly, the positive sign on $\ln (\mathrm{MV})$ for both the existing and new stocks, and the negative sign for the non-markup stocks suggest that fund managers prefer to use stocks with larger capitalization for the markup. And, the result of the coefficients on the $\mathrm{IHI}$ indicates that fund managers in general prefer stocks with higher institutional ownership for the markup. Next, from the fact that most of the coefficients on MQRTN, which represents the market return in the previous month, are insignificant in general for both the existing and new target stocks while significantly positive for the non-markup stocks implies that fund managers do not chase the market in their holdings markup.

As for the INDTY variable, which represents the hi-tech stocks, the coefficients are in general positive for the existing target stocks and all negative for the nonmarkup stocks. This result implies that hi-tech stocks are more popular to the fund managers in their holdings markup.

Finally, the coefficients of HERD are either negative or insignificant for both the existing and new target stocks, while they are all significantly positive for the nonmarkup stocks. This indicates that non-markup stocks tend to be those with higher degree of herding, while markup target stocks as a whole tend to be those with lower or no herding. This result implies that fund managers have a tendency not to pick those stocks that other managers tend to herd on to be the markup targets, no matter they are stocks currently in their portfolios or stocks that they have not held. Thus, according to the above results, mutual funds herding does play a role in the funds holdings markup behavior. That is, fund managers tend to avoid those stocks that other fund managers tend to herd on when they mark up the holdings. This makes sense because the reason why a fund manager marks up her fund holdings is to enhance the fund ranking among all of the funds. And, in order to achieve that goal it would be more effective if she tries to avoid herding with other funds, so that her fund's ranking can be standing out among other funds.

\section{Conclusions}


This paper uncovers a seasonal mutual fund holdings markup pattern in Taiwan's market. Specifically, we find that fund's holdings jump up significantly at the quarter-ends while drop back immediately to the previous level in the following month. And this phenomenon is more pronounced at the end of the fourth quarter, i.e., year-end. The holdings markup pattern found in this paper may look similar to the price markup found by Carhart et al. ([ 4] ) in the US market. And, both of the two phenomena may be based on the same motivation of the fund managers trying to inflate their fund performance at the quarter-ends and yearend when evaluations on funds are usually taking place. However, the mechanism and the implications from both of the patterns can be different.

First of all, the price markup pattern found by Carhart et al. ([ 4] ) implies that fund managers tend to demand more shares and push up the prices of the stocks already held in the fund. However, the holdings markup phenomenon implies that fund managers may have alternative ways to inflate their portfolio performance. Pushing up the price for the stocks that a fund has already held is only one of the two ways to inflate a fund's performance. Another way is to buy shares that are not already held in a fund's current portfolio but are expected to have a higher future return. We document that fund managers tend to also use new stocks in marking up their portfolio holdings, although majority of the stocks fund managers use are the ones that are already held in their portfolios, which is consistent with the portfolio pumping documented in the literature.

Secondly, Carhart et al. ([ 4] ) do not show directly whether there exists markup on the holdings in addition to that on the price. Our study fills this gap by explicitly examining the holdings markup. Furthermore, we also explore the characteristics of the stocks that fund managers prefer for their holdings markup and find that fund managers prefer to use growth stocks, stocks with larger capitalization, with higher institutional ownership, in the hi-tech industry, and stocks with higher earnings quality, as their targets for the holdings markup. Since those stocks are more frequently traded and thus are more liquid, this indicates that fund managers try to limit the risk, especially liquidity risk, in their holdings markup strategy. 
Another stock characteristic that we find for the markup target is that fund managers tend to avoid stocks with high degree of herding. This makes sense because it would be more effective in terms of enhancing a fund's relative ranking among all of the funds if the fund manager tries to avoid those stocks that are already being herded by other managers, so that her fund's ranking may stand out among the funds.

Finally, it is worth noting that since the holdings markup activity involves the share buying at the quarter-ends and year-end followed by immediate selling of those shares in the following month, it would essentially impair the fund's performance due to the potentially high transaction costs involved. This, in turn, can be quite detrimental to the fund investors' benefits. Thus, fund managers' such regular holdings markup activities may lead to an agency problem. More importantly, such seemingly redundant trading activities by mutual fund managers need to draw more attentions from the mutual fund regulators for the best interest of the fund's investors.

\section{References}

\section{Citations}

1 Bhargava R, Gallo JG, Swanson PE, The performance, asset allocation, and investment style of international equity managers, Rev Quant Finance Account, 2001, 17, 377, 395, 10.1023/A:1012787714784

- 2 Bhattacharyya S, Nanda V, Portfolio pumping, trading activity and fund performance, Rev Finance, 2013, 17, 885, 919, 10.1093/rof/rfs017

- 3 Brown KC, Harlow WV, Starks LT, Of tournament and temptations: an analysis of managerial incentives in the mutual fund industry, J Finance, 1996, $51,85,110,10.1111 /$ j.1540-6261.1996.tb05203.x

- 4 Carhart MM, Kaniel R, Musto DK, Reed AV, Leaning for the Tape:

evidence of gaming behavior in equity mutual funds, J Finance, 2002, 57, 661, $693,10.1111 / 1540-6261.00438$

- 5 Chan LK, Jegadeesh N, Lakonishok J, Momentum strategies, J Finance, 1996, 51, 1681, 1713, 10.1111/j.1540-6261.1996.tb05222.x 
- 6 Chen ML, Lin FL, Hung MC, Wang KL, Investment preference and strategies of foreign institutional investors across different industries in Taiwan, Rev Pac Basin Financ Mark Polic, 2009, 12, 675, 694, 10.1142/S0219091509001824

- 7 Christie WG, Huang RD, Following the pied piper: do individual returns herd around the market?, Financ Anal J, 1995, 51, 4, 31, 37, 10.2469/faj.v51.n4.1918

- 8 Cohen SI, Starks LT, Estimation risk and incentive contracts for portfolio managers, Manag Sci, 1988, 34, 1067, 1079, 10.1287/mnsc.34.9.1067

- 9 Falkenstein EG, Preferences for stock characteristics as revealed by mutual fund portfolio holdings, J Finance, 1996, 51, 111, 135, 10.1111/j.15406261.1996.tb05204.x

- 10 Golec JH, Empirical tests of principal-agent model of the investment advisor relation, J Financ Quant Anal, 1992, 27, 91, 95, 10.2307/2331299

- 11 Grinblatt M, Titman S, How to evaluate a portfolio manager, Finance Mark Portf Manag, 1987, 1, 9, 20

- 12 Grinblatt M, Titman S, Adverse risk incentives and design on performance -base contract, Manag Sci, 1989, 35, 807, 822, 10.1287/mnsc.35.7.807

- 13 Grinblatt M, Titman S, Wermers R, Momentum investment strategies, portfolio performance, and herding: a study of mutual fund behavior, Am Econ Rev, 1995, 85, 1088, 1105

- 14 Grinold R, Rudd A, Incentive fees: Who wins? Who loses?, Financ Anal J, 1987, 43, 27, 38, 10.2469/faj.v43.n1.27

- 15 Haugen R, Lakonishok J, The incredible January effect: the stock market's unsolved mystery, 1988, Homewood, Dow-Jones-Irwin

- 16 Hu G, McLean RD, Pontiff J, Wang Q, The year-end trading activities of institutional investors: evidence from daily trades, Rev Financ Stud, 2014, 27, 1593, 1614, 10.1093/rfs/hht057

- 17 Ippolito RA, Consumer reaction to measurement of poor quality: evidence from the mutual fund industry, J Law Econ, 1992, 35, 45, 70, 10.1086/467244

- 18 Jegadeesh N, Titman S, Returns to buying winners and selling losers: implications for stock market efficiency, J Finance, 1993, 48, 65, 91, 10.1111/j.1540-6261.1993.tb04702.x 
- 19 Keim D, Size-related anomalies and stock return seasonality: further empirical evidence, J Finance, 1983, 12, 13, 32

- 20 Musto D, Investment decisions depend on portfolio disclosure, J Finance, 1999, 54, 935, 952, 10.1111/0022-1082.00132

- 21 Orphanides A (1996) Compensation incentives and risk taking behavior: evidence from mutual funds. Working paper

- 22 Roll RW, Vas ist das?The turn of the year effect and the return premium of small firms, J Portf Manag, 1983, 9, 18, 28, 10.3905/jpm.1983.18

- 23 Sirri ER, Tufano P, Costly search and mutual fund flows, J Financ, 1998, $53,1589,1622,10.1111 / 0022-1082.00066$

- 24 Starks L, Performance incentive fees: an agency theoretic approach, J Financ Quant Anal, 1987, 22, 17, 32, 10.2307/2330867

- 25 Wermers R, Mutual fund herding and the impact on stock prices, J Finance, 1999, 54, 581, 622, 10.1111/0022-1082.00118

- 26 Zweig J, Watch out for the year-end fund filmflam, Money Mag, 1997, 26, 130, 133

\section{Footnotes}

1 We are unable to examine directly the price markup pattern evidenced by Carhart et al. (2002) due to lack of trading data on Taiwan's market. However, the results shown in Table 4 are similar to the price markup where the increase of returns in NAVs at the quarter-ends represents the price markup of the funds.

2 Hu et al. (2014) also point out that there is no direct evidence that institutional investors' trading activities at the quarter-ends or year-end are related to buying winners or selling losers.

3 In Taiwan, equity-in-general funds are required to hold at least $70 \%$, but no more than 95\%, of equity securities. Small-cap funds are required to hold mid to small-size stocks with market capitalization less than NT\$8 billion, with their stock holdings subject to the same 70-95\% restriction of their fund sizes. The balanced funds may hold both stocks and bonds, while their stock holdings are limited to $75 \%$ of their fund sizes. And the high-tech funds are equity funds whose holdings are concentrated on the high-tech industry. 
4 It is worth noting that the seasonal return pattern of the holdings markup shown in Table 4 is quite different from, and not related to, the "turn-of-theyear effect" ("January effect"). If they are related, then we should see a significant positive excess return of the holdings markup at the year-end. However, in fact those excess returns at the year-end from Table 4 for various fund styles are actually all showing negative signs, which indicates that the return seasonal pattern of the holdings markup is not caused by the "turn-ofthe-year effect".

5 For example, Grinblatt et al. (1995) and Wermers (1999) both evidence the herding behavior of mutual funds. Furthermore, Falkenstein (1996) documents that fund managers tend to prefer stocks with some specific characteristics, which may also lead to the fund managers' herding behavior.

6 In a separate table that is not reported here, we also look at the holdings percentage for each of the fund categories and all of the numbers are quite similar to those in the "All Funds" sample.

7 For example, both Hu et al. (2014) and Bhattacharyya and Nanda (2013), among others, have found significant portfolio pumping by the institutional investors.

PHOTO (COLOR)

PHOTO (COLOR)

PHOTO (COLOR)

PHOTO (COLOR)

PHOTO (COLOR)

PHOTO (COLOR) 


\section{PHOTO (COLOR)}

\section{PHOTO (COLOR)}

By Ching-Chang Wang and Jerry Yu

Review of Quantitative Finance \& Accounting is a copyright of Springer, 2018. All Rights Reserved.

Get help from a librarian at Robert L. Bogomolny Library!

$\begin{array}{ll:lll}\text { iPhone and Android apps } & \text { EBSCO Support Site } & \text { Privacy Policy } & \text { A/B Testing } & \text { Terms of Use }\end{array}$ Copyright Contact Us

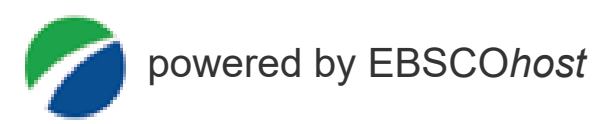

(C) 2019 EBSCO Industries, Inc. All rights reserved. 